\title{
Survival strategies and pathogenicity of Ralstonia solanacearum phylotype II subjected to prolonged starvation in environmental water microcosms
}

Correspondence

Elena G. Biosca

elena.biosca@uv.es

Received 10 April 2008

Revised 3 August 2008

Accepted 13 August 2008
Belén Álvarez, ${ }^{1}$ María M. López ${ }^{1}$ and Elena G. Biosca ${ }^{2}$

${ }^{1}$ Instituto Valenciano de Investigaciones Agrarias (IVIA), Carretera de Moncada a Náquera km 4.5, Moncada 46113, Valencia, Spain

${ }^{2}$ Departamento de Microbiología y Ecología, Universidad de Valencia, Av. Dr Moliner 50, Burjasot 46100, Valencia, Spain

\begin{abstract}
Survival strategies exhibited over 4 years by Ralstonia solanacearum phylotype (ph) II biovar (bv) 2 in environmental water microcosms were examined. The bacterium is a devastating phytopathogen whose ph II bv 2 causes bacterial wilt in solanaceous crops and ornamental plants. Outbreaks of the disease may originate from dissemination of the pathogen in watercourses, where it has to cope with prolonged nutrient limitation. To ascertain the effect of long-term starvation on survival and pathogenicity of $R$. solanacearum in natural water microcosms, survival experiments were conducted. Microcosms were prepared from different sterile river water samples, inoculated separately with two European strains of ph II at $10^{6}$ c.f.u. $\mathrm{ml}^{-1}$ and maintained at $24{ }^{\circ} \mathrm{C}$ for 4 years. In all assayed waters, starved $R$. solanacearum remained in a non-growing but culturable state during the first year, maintaining approximately the initial numbers. Thereafter, part of the population of $R$. solanacearum progressively lost the ability to form colonies, and non-culturable but metabolically active cells appeared. During the whole period, the bacterium remained pathogenic on host plants and underwent a transition from typical bacilli to small cocci which tended to aggregate. Some starved $R$. solanacearum cells filamented and formed buds. Starvation response, viable but non-culturable state, morphological changes and aggregation have not previously been reported for this pathogen as survival mechanisms induced in oligotrophic conditions. The potential existence of long-starved pathogenic cells in environmental waters may raise new concerns about the epidemiology of bacterial wilt disease.
\end{abstract}

\section{INTRODUCTION}

Bacterial wilt affects numerous crops and some ornamental plants worldwide (Elphinstone, 2005; Hayward, 1994). The causative agent is the Ralstonia solanacearum species complex (Fegan \& Prior, 2005), classified into phylotypes and biovars according to molecular and biochemical characteristics respectively (Fegan \& Prior, 2005; Hayward, 1991). It is considered a quarantine organism in the European Union (Anonymous, 2000) and a potential bioterrorism agent in the USA (Lambert, 2002). The bacterium is soil and water borne, waterways being major dissemination routes in the environment (Elphinstone, 2005). It enters the plant through the roots and colonizes the vascular system, producing severe disease (Hayward, 1991; Kelman, 1953). After destruction of the plant, an inter-host life period has been proposed for this pathogen (Denny et al., 1994), where it would have to cope with the

Abbreviations: bv, biovar; DVC, direct viable count; ph, phylotype; VBNC, viable but non-culturable. stress of oligotrophic habitats. Survival studies in sterile water have reported persistence of the bacterium for variable periods (Kelman, 1956; van Elsas et al., 2001; van Overbeek et al., 2004; Wakimoto et al., 1982), and occasional capacity to wilt susceptible hosts (Caruso et al., 2005; van Overbeek et al., 2004). Although some environmental factors affecting $R$. solanacearum physiology have been reviewed (Hayward, 1991; Kelman, 1953; van Elsas et al., 2005), knowledge of the survival strategies used by this pathogen under prevailing starvation in aquatic habitats is still scarce (López \& Biosca, 2005).

Micro-organisms can resort to diverse mechanisms when confronted with nutrient deprivation (Morita, 1997). Several starvation-survival responses have been described, with starved bacterial populations maintaining their numbers over time in a non-growing but culturable state at different levels depending on the species (Morita, 1997). This starvation-induced state for survival proved to be distinctly different from that of active growth (Heim et al., 2002). Under prolonged oligotrophy, reduction in cell size 
and change to a round cell shape are also considered as bacterial strategies to survive in the environment (Novitsky \& Morita, 1976; Rollins \& Colwell, 1986; Ruiz et al., 2001), as well as the induction of a viable but non-culturable (VBNC) state (Oliver, 2005; Roszak \& Colwell, 1987) that constitutes a distinct physiological state from that of the starvation response (Heim et al., 2002). R. solanacearum becomes VBNC by exposure to copper (Grey \& Steck, 2001) and after incubation at low temperature in soil and water (Caruso et al., 2005; van Elsas et al., 2000, 2001; van Overbeek et al., 2004). Adaptations to oligotrophy have not previously been described for $R$. solanacearum.

The occurrence of disease outbreaks linked to the presence of $R$. solanacearum phylotype (ph) II biovar (bv) 2 in European waterways (Caruso et al., 2005; van Elsas et al., 2000, 2001), together with the existence of European Union (EU) Directives banning irrigation of host plants with contaminated water (Anonymous, 1998, 2000, 2006), makes the establishment of $R$. solanacearum in non-host environments a matter of concern. As the life of $R$. solanacearum in water is still little known, this work aimed to investigate the survival mechanisms exhibited by ph II bv 2 of this pathogen in response to nutrient deprivation in environmental water microcosms over 4 years.

\section{METHODS}

Bacterial strains and culture conditions. Strain IVIA-1602.1 of $R$. solanacearum ph II bv 2, isolated from potatoes with brown rot symptoms in Spain, was used in all experiments, and the Dutch strain IPO-1609 (also ph II bv 2) (van Elsas et al., 2001), kindly provided by J. D. van Elsas, was included for comparison. Strains were kept at $-80{ }^{\circ} \mathrm{C}$ in a $30 \%(\mathrm{v} / \mathrm{v})$ glycerol medium and were grown on nonselective Yeast Peptone Glucose Agar (YPGA) (Ridé, 1969) with filtersterilized glucose, for $72 \mathrm{~h}$ at $29^{\circ} \mathrm{C}$.

Characteristics of water samples. Four river water samples were collected from different sites in Spain (Caruso et al., 2005), and each of them was separately used for survival experiments. Mineral nutrient concentrations ranged as follows, depending on the water sample (values per litre): Na, 5.7-12.2 mg; K, 1.4-1.6 mg; Mg, 3.5-3.8 mg; Ca, 10.3$12.2 \mathrm{mg} ; \mathrm{Fe}, 0.21-0.25 \mathrm{mg} ; \mathrm{Mn}, 0.04-0.06 \mathrm{mg} ; \mathrm{NO}_{3}^{-}, 4.5-6.8 \mathrm{mg}$, and $\mathrm{P}_{2} \mathrm{O}_{5}, 0.24-0.36 \mathrm{mg}$. Organic matter contents estimated by biochemical oxygen demand were $<1.8 \mathrm{mg} \mathrm{O}_{2} \mathrm{l}^{-1} ; \mathrm{pH}$ values of the different water samples were around neutrality, from 6.5 to 7.3 .

Preparation of water microcosms. Survival experiments were conducted similarly to Caruso et al. (2005). For each of the four water samples, three microcosms were prepared. Each microcosm was composed of $200 \mathrm{ml}$ river water filtered through $0.22 \mu \mathrm{m}$ pore-size filters, autoclaved, and then inoculated with strain IVIA-1602.1 or IPO1609 in PBS at $\mathrm{pH} 7.2$, to give a final concentration of $0.5 \%\left(5 \times 10^{6}\right.$ c.f.u. $\mathrm{ml}^{-1}$ ). After inoculation, the microcosms were incubated for 4 years at $24 \pm 1{ }^{\circ} \mathrm{C}$. This temperature was selected because it was the nearest to the optimum for $R$. solanacearum growth that had been registered in some Spanish rivers in warm months (Caruso et al., 2005).

Bacterial cell counts. Microscopic counts for total and viable $R$. solanacearum cells and plate counts for culturability were performed from each microcosm as described previously (Álvarez et al., 2007) at inoculation time (day 0 ) and days 1, 2, 4, 8, 14, 28 and 40; also at 2, 3 and 6 months, and every 6 months up to 4 years of incubation. For total and viable cell counts, aliquots from the microcoms were incubated with yeast extract and nalidixic acid according to a direct viable count (DVC) method (Kogure et al., 1979), for 16 h (van Elsas et al., 2001) except with long-starved cells, for which the incubation was prolonged up to $72 \mathrm{~h}$. Cells were fixed with $2 \%(\mathrm{v} / \mathrm{v})$ formaldehyde and stained with $0.1 \%(\mathrm{w} / \mathrm{v})$ acridine orange (Oliver, 1987). Long-starved cells were additionally stained by indirect immunofluorescence (Anonymous, 1998, 2006), with the polyclonal antiserum 1546-H IVIA against $R$. solanacearum (Caruso et al., 2005), to determine possible changes in surface antigens. Viable cells were also measured by the Live/Dead BacLight Bacterial Viability kit (Molecular Probes) in some of the assays. After mixing cells and dyes (SYTO 9 and propidium iodide) bacterial cells can be counted as alive or dead in terms of membrane integrity (Boulos et al., 1999). Mixtures were incubated in the dark at $24 \pm 1{ }^{\circ} \mathrm{C}$ for $15 \mathrm{~min}$, and up to $1 \mathrm{~h}$ in the case of long-starved cells. Bacterial cells were visualized with a Leica epifluorescence microscope at a magnification of $\times 1250$ and counted in at least 20 random fields. For culturability, plate counts on YPGA were done after at least $72 \mathrm{~h}$ at $29^{\circ} \mathrm{C}$.

Cell size and shape. Microcosm aliquots were taken at some sampling times and cells were directly fixed and stained either by immunofluorescence or with acridine orange as described above, without being incubated for viability tests. $R$. solanacearum cell morphology was observed with a Nikon Eclipse E800 microscope at a magnification of $\times 1000$. Pictures were taken with an adapted digital camera using ACT-1 for DXM1200 software, and no processing of the images was performed. Cell size was determined according to the software Image-Pro Plus (Media Cybernetics). For each sample, at least 300 cells were measured in length and width, and cell volumes were calculated.

\section{In planta pathogenicity assays}

Stem inoculation. Microcosm aliquots were stem-inoculated in nonaxenic tomato plants (Lycopersicon esculentum 'Roma') susceptible to $R$. solanacearum, at time zero, 1, 2, 3 and 6 months, 1 year, and then every 6 months up to 4 years of microcosm incubation. Inoculations were performed by injecting into the stem $10 \mu$ directly taken from the water microcosms during the first year, and thereafter with $50 \mu$ l. Groups of 14 plants grown in greenhouse conditions from seeds tested to be $R$. solanacearum-free were used. All stem inoculations were done with aliquots from strain IVIA-1602.1-inoculated microcosms from the four water samples, in triplicate. For comparative purposes, assays with aliquots from strain IPO-1609-inoculated microcosms were also performed. In all cases, PBS and a fresh bacterial suspension of either strain IVIA-1602.1 or IPO-1609 as negative and positive controls were used. During incubation in a growth chamber $\left(26^{\circ} \mathrm{C}, 16 \mathrm{~h}\right.$ day; $22^{\circ} \mathrm{C}$, $8 \mathrm{~h}$ night; $70 \%$ relative humidity) under quarantine conditions, inoculated plants were periodically monitored for up to 6 weeks for appearance of symptoms and disease development. Stems from wilted plants were cut at different levels above the inoculation point and segments of $2-3 \mathrm{~cm}$ were analysed for presence of $R$. solanacearum. Extracts were plated onto a modified semiselective medium South Africa (SMSA) agar (Elphinstone et al., 1996) and colonies were PCRtested (OLI1 Y2 primers) as described in EU Directives (Anonymous, 1998, 2006). Stems from inoculated non-wilted plants were processed in the same way after 6 weeks.

Watering inoculation. Volumes of $20 \mathrm{ml}$ from the microcosms were used after one-fold dilution, to water groups of 10 'Roma' tomato plants at time zero and after 2 and 4 years of microcosm incubation. Assays were performed with water microcosms inoculated with either strain IVIA-1602.1 or IPO-1609. Controls, monitoring and analyses of plants were as described above. 
Statistical analysis. Each survival and pathogenicity assay was done independently with $R$. solanacearum-inoculated microcosms from four different water samples in triplicate. For survival experiments, logtransformed data of total, viable and culturable $R$. solanacearum cell counts were analysed by using mean values. Significant differences were assessed by variance analysis (ANOVA). Factors considered for the analysis were: water sample, time of incubation and bacterial strain. For pathogenicity experiments, results were analysed by the Fisher's exact test for categorical data to study possible differences between the two inoculation methods, the two bacterial strains and among the four water samples. In all cases, differences were recorded as significant at $P<0.05$.

\section{RESULTS}

\section{Effect of long-term starvation on $\boldsymbol{R}$. solanacearum survival in environmental water microcosms}

Within 1, 2, 3 and 6 months, and approximately by the first year post-inoculation in river water microcosms at $24{ }^{\circ} \mathrm{C}$, total $R$. solanacearum strain IVIA-1602.1 populations remained at approximately $2-6 \times 10^{7}$ cells $\mathrm{ml}^{-1}$ (Fig. 1 ). In this period, metabolically active cells measured by the DVC method remained at around $1-2 \times 10^{7}$ cells $\mathrm{ml}^{-1}$ (Fig. 1), with comparable values obtained by the Live/Dead kit, and culturability ranged between 3 and $8 \times 10^{6}$ c.f.u. $\mathrm{ml}^{-1}$, depending on the water sample (Fig. 1). During the second, third and fourth year, the numbers of total bacterial cells slightly increased up to values from $9 \times 10^{7}$ to $2 \times 10^{8}$ cells $\mathrm{ml}^{-1}$ (Fig. 1). In this period and until 30-36 months postinoculation, viable $R$. solanacearum cells measured by the DVC method and Live/Dead kit also increased, remaining at levels around $0.5-1 \log$ units below the total cell numbers. From $30-36$ to 48 months, decreases in nutrient-responsive cells to values around $1-3 \times 10^{6}$ cells ml $^{-1}$ were observed (Fig. 1), while Live/Dead counts revealed roughly 3-6 $\times 10^{7}$ cells $\mathrm{ml}^{-1}$ retaining intact membranes, depending on the water sample. Culturable $R$. solanacearum populations declined from approximately the first year post-inoculation to the end of the experiments, reaching values of $8 \times 10^{3}$ to $4 \times 10^{4}$ c.f.u. $\mathrm{ml}^{-1}$ (Fig. 1). For each water sample, significant differences $(P<0.05)$ were observed among total, viable and culturable counts, although trends in total, viable and culturable populations among the four water samples remained similar $(P>0.05)$ (Fig. 1). The stronger decreases in culturability with respect to viability $(P<0.05)$ in all waters assayed indicated the entry of some of the bacterial population into the VBNC state. On plates, the colonies of $R$. solanacearum that were still culturable had a typical smooth morphology with a normal size.

In the comparative experiments using the IPO-1609 strain, survival curves showed trends similar to those of strain IVIA-1602.1 $(P>0.05)$ (data not shown).
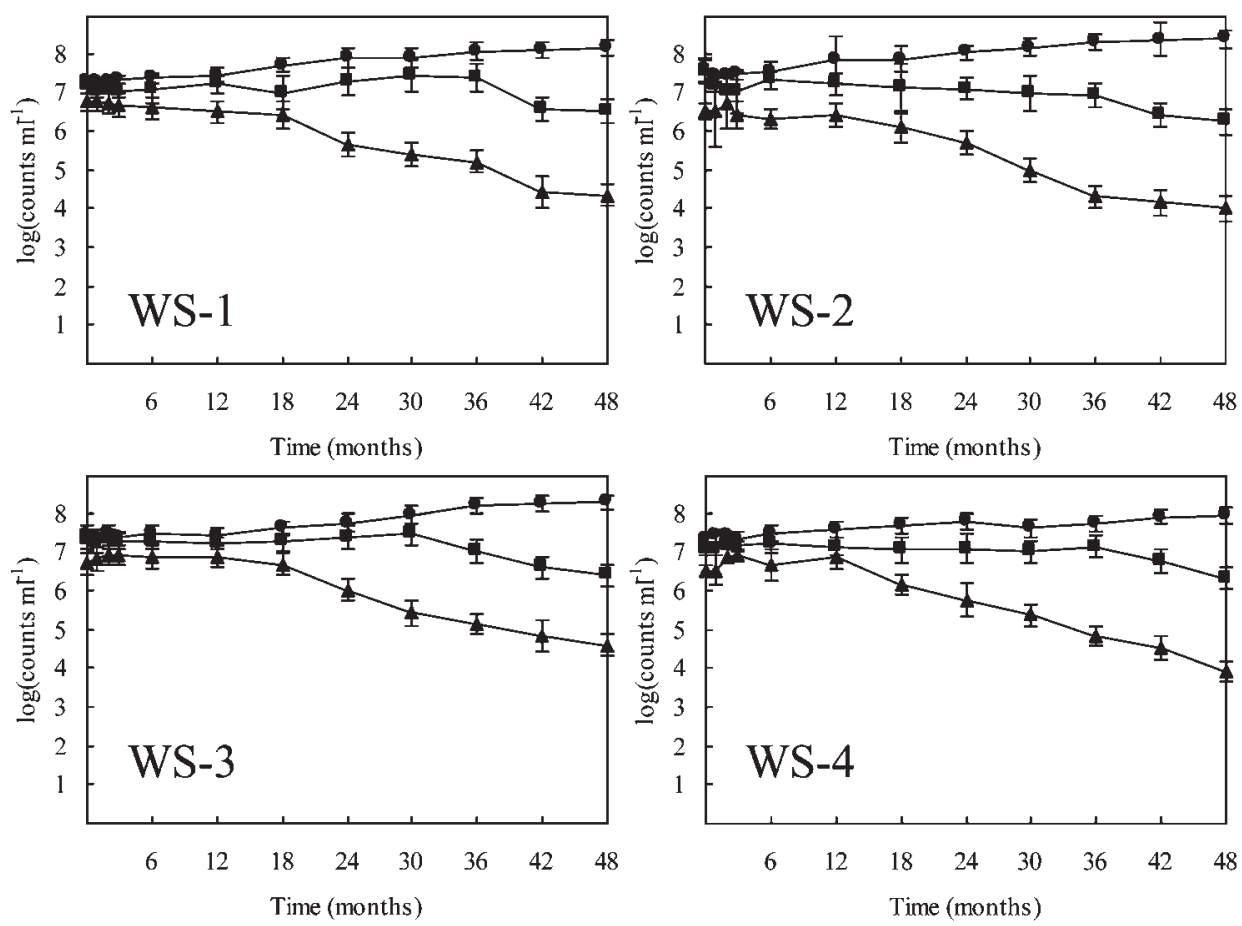

Fig. 1. Survival curves of $R$. solanacearum ph II bv 2 strain IVIA-1602.1 over 4 years in river water microcosms at $24{ }^{\circ} \mathrm{C}$ : WS-1, water sample 1; WS-2, water sample 2; WS-3, water sample 3; WS-4, water sample 4. The graphs show total ( $)$ and viable $(\boldsymbol{\square})$ cells, and colony-forming units on YPGA ( $\mathbf{\Delta})$. Points represent means \pm SD. 

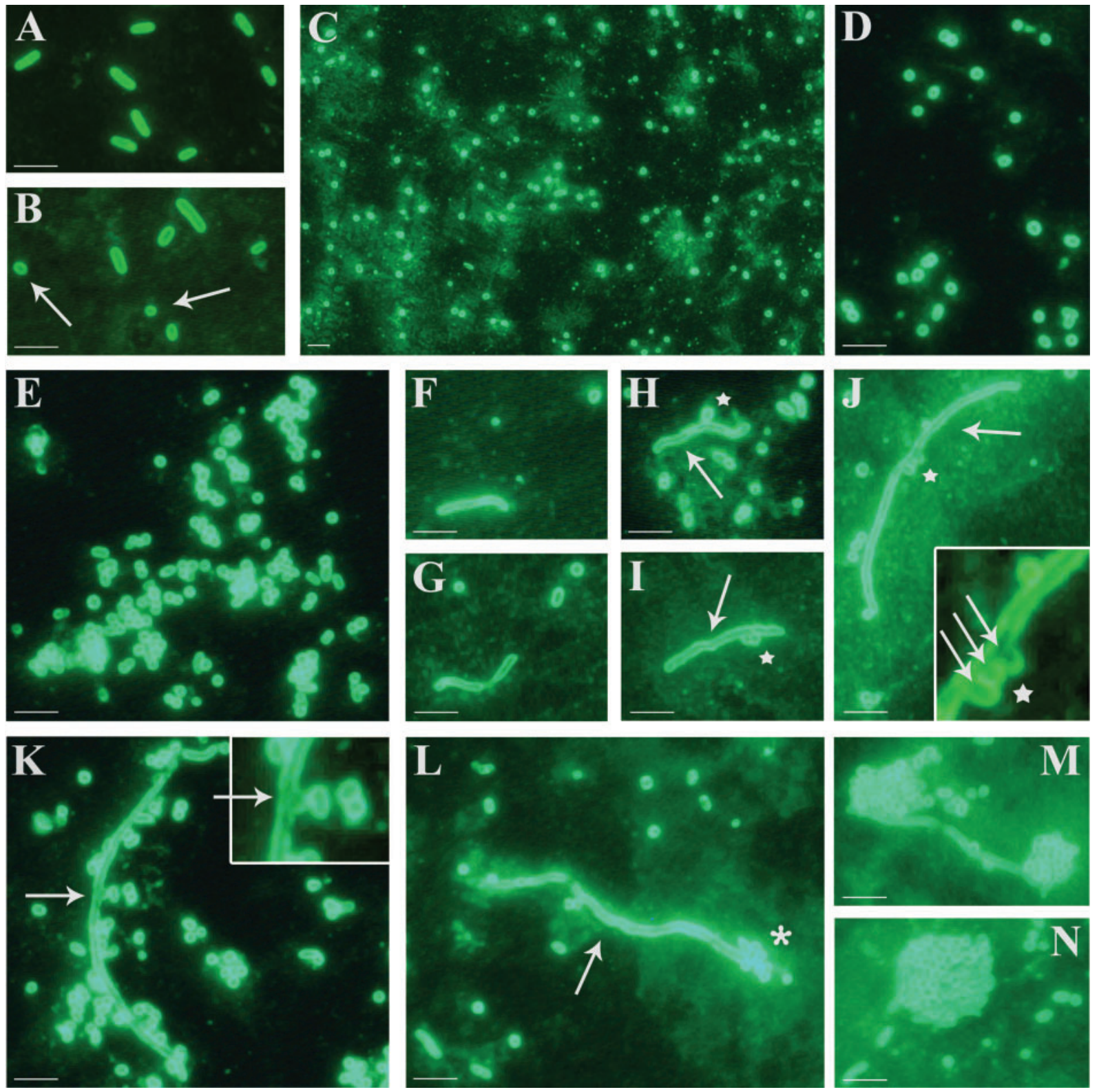

Fig. 2. Microscopic observations of the changes in morphology of $R$. solanacearum ph II bv 2 strain IVIA-1602.1 under starvation in river water microcosms at $24^{\circ} \mathrm{C}$. (A) Freshly grown cells, with typical bacillar form. (B) One-month starved cells; co-existence of bacillar and coccoid forms (arrows). (C) Four-year starved cells; majority of coccoid forms. (D) Detail of coccoid forms in the fourth year. (E) Aggregates of coccoid forms. (F) Filamentous cells formed individually or $(G)$ in pairs. $(H, I, J)$ Suspensor cells (arrows) with buds (stars), either one (H), two (I) or more (J) per cell. (K) Suspensor cell developing a bud (arrow) surrounded by coccoid forms and small aggregates. The insets in $\mathrm{J}$ and $\mathrm{K}$ (higher magnifications of the arrowed areas) show basal parts of developing buds lacking a cell wall (arrows). (L) Coccoid forms at the extremities of a suspensor cell (arrow), either as incipient aggregates (asterisk) or (M) developing aggregates. (N) Detail of a well-formed aggregate. Bacteria were visualized at a magnification of $\times 1000$ after specific immunofluorencence staining. Scale bars, $2.5 \mu \mathrm{m}$.

\section{Effect of long-term starvation on $\boldsymbol{R}$. solanacearum cell morphology in environmental water microcosms}

Freshly growing cells of $R$. solanacearum strain IVIA-1602.1 have a bacillar form (Fig. 2A). However, from the first days of starvation and depending on the water sample, coccoid forms were observed up to $1.7 \%$, progressively increasing to $7-10 \%$ by the first week and to $25-30 \%$ by 1 month (Fig. 2B). By 1 year, coccoid forms had increased to about $40-50 \%$, by the second year to $60-70 \%$, and after 4 years 
to $80-90 \%$ (Fig. 2C, D), with a general tendency to aggregate (Fig. 2E). At inoculation time cells had the following sizes (mean $\pm \mathrm{SD}$ ): length, $1.5 \pm 0.3 \mu \mathrm{m}$; width, $0.5 \pm 0.1 \mu \mathrm{m}$; and volume, $0.20 \pm 0.07 \mu \mathrm{m}^{3}$. After 4 years the cells had reduced in size, showing a mean diameter of $0.65 \pm 0.2 \mu \mathrm{m}$ and a mean volume of $0.14 \pm 0.08 \mu \mathrm{m}^{3}$. Volume reduction ranged from 18 to $77 \%$.

During the long-term starvation, filamentous, elongated forms of $R$. solanacearum were observed (Fig. 2F, G). Some longer filamentous cells showed localized expansions or buds which maintained a cell wall, as evidenced by immunofluorescence (Fig. 2H-J). Cells of this type have been referred to as suspensor cells (Thomas et al., 1999). Whereas individual filamentous cells were observed to form buds along the cell (Fig. 2H-J), sometimes surrounded by coccoid aggregates (Fig. 2K), filamentous cells in pairs had the budding points at their extremities (Fig. 2L, M). Well-formed aggregates were, at least superficially, composed of coccoid forms (Fig. 2N). Acridine orange staining showed that filamentous cells, coccoid forms, buds and aggregates contained nucleic acid. In comparative experiments, strain IPO-1609 similarly changed shape, reduced size and filamented.

\section{Effect of long-term starvation in environmental water microcosms on $\boldsymbol{R}$. solanacearum pathogenicity and water-borne transmission}

Cells of $R$. solanacearum strain IVIA-1602.1 starved in microcosms from different water samples retained diseaseinducing capacity up to the fourth year, as shown in Table 1. As expected, wilting percentages were significantly $(P<0.05)$ higher by stem inoculation than by watering, except at time zero (Table 1). For stem inoculation, in general and regardless of the time period for which cells were under starvation, tomato plants started wilting at around 1 week, with a similar pace of symptom

Table 1. In planta pathogenicity assays of $R$. solanacearum ph II bv 2 strain IVIA-1602.1 long-starved in river water microcosms, on tomato plants 'Roma'

Water microcosms were from: WS-1, water sample 1; WS-2, water sample 2; WS-3, water sample 3; and WS-4, water sample 4. Control plants inoculated with $R$. solanacearum strain IVIA-1602.1 yielded $100 \%$ wilting in stem inoculation and 93-100\% wilting in watering inoculation. Plants inoculated with PBS were negative. Data represent mean values from triplicate assays. Standard deviation intervals: for $R$. solanacearum plant inocula $\pm 0.16 \log$ (c.f.u. per plant) and $\pm 0.05 \log$ (c.f.u. per pot); and for wilting $\pm 3.34 \%$ in stem inoculation and $\pm 5.95 \%$ in watering inoculation.

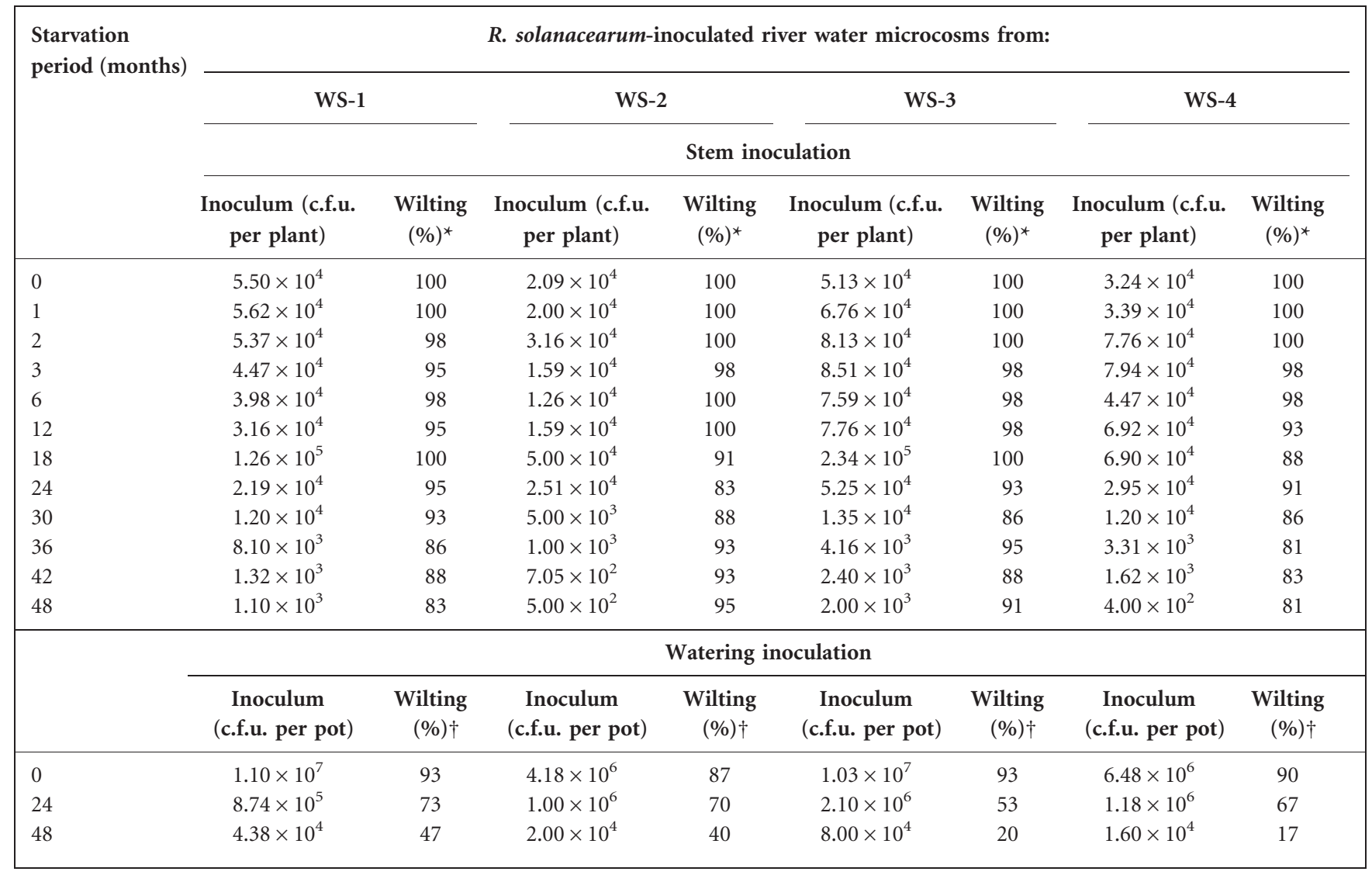

${ }^{*}$ Value corresponding to $100 \%=42$ tomato plants $(14 \times 3$ sets of plants $)$.

$\dagger$ Value corresponding to $100 \%=30$ tomato plants $(10 \times 3$ sets of plants $)$. 
development with respect to the positive controls. At approximately 2 weeks post-inoculation, about $25-40 \%$ of the inoculated tomato plants were wilting and by 3 weeks $80-100 \%$ showed severe disease (Table 1); the pathogen was reisolated from all of them on SMSA, and PCRidentified. On plates, colonies of $R$. solanacearum were typically smooth. The inoculated tomato plants remaining nonwilted after 6 weeks (up to $20 \%$ ) were also processed, and the bacterium was detected in about $70 \%$ of them at distances $2-16 \mathrm{~cm}$ from the inoculation point, proving the infectivity and spread of the inoculum. Differences observed among the four water samples were not significant $(P>0.05)$ (Table 1$)$.

In watering inoculation assays, $R$. solanacearum strain IVIA-1602.1 starved cells caused wilting of the tomato plants within 6 weeks after plant inoculation, even 4-yearstarved cells (17-47\%; Table 1). Appearance of symptoms was roughly at 2 weeks post-inoculation, with an irregular pace of disease spread in the sets of plants inoculated with the different microcosm samples (data not shown). The pathogen was reisolated and identified from the wilted plants, and colonies grown on SMSA were smooth. In both stem and watering inoculations, negative control plants did not show any disease symptoms.

Comparative pathogenicity assays performed with the Dutch IPO-1609 strain yielded similar results in stem inoculation $(P>0.05)$ ( $76-91 \%$ of the tomato plants wilted when inoculated with 4-year-starved cells, depending on the water sample). This strain was also capable of waterborne transmission of the disease, although to a lesser extent (10-23\% of the plants by the fourth year, depending on the water sample).

\section{DISCUSSION}

R. solanacearum ph II bv 2 survival strategies during longterm exposure to oligotrophic conditions were investigated in environmental water microcosms. To our knowledge, this is the longest monitoring of $R$. solanacearum behaviour in a non-host environment, and the results support the great potential for persistence of this pathogen, retaining its disease-inducing capacity.

$R$. solanacearum was able to survive under conditions of extended nutrient limitation in sterile river waters, exhibiting diverse survival mechanisms. One of them was a starvation response consisting of maintaining populations in a non-growing but culturable state, as commonly described for other bacterial species (Morita, 1997) but not for $R$. solanacearum as such up to now. Previous studies on survival of the pathogen were performed in sterile pure water (Kelman, 1956; van Overbeek et al., 2004; Wakimoto et al., 1982) or sterile natural water only for several months (Kelman, 1956; van Elsas et al., 2001) to a maximum of 1 year (Tanaka \& Noda, 1973). During the starvation period in river water microcosms, proportions of the viable $R$. solanacearum populations progressively lost the ability to form colonies on plates, as already observed in starved bacteria (Besnard et al., 2000; Colwell \& Huq, 1994), becoming VBNC as another survival strategy under prolonged oligotrophy. Nutrient deprivation has been recognized as an important stimulus to induce the VBNC state, which represents a common strategy for bacterial survival in energy-deficient environments (Colwell \& Huq, 1994; Oliver, 2005). Starvation as a VBNC-inducing factor has not been reported previously for $R$. solanacearum.

Increase in the total and viable $R$. solanacearum population during long starvation could be due to the occurrence of cell division, observed for other bacterial species under nutrient deprivation (Byrd, 2000) and considered a survival strategy for bacteria facing adverse environmental conditions (Byrd, 2000; Morita, 1997; Roszak \& Colwell, 1987). Multiplying the number of individuals raises the probability of one surviving cell, enabling dissemination and colonization of new ecological niches, which implies a selective advantage for diversification of a bacterial species (Morita, 1997). These cell divisions might have been produced by cryptic growth (Roszak \& Colwell, 1987) at the expense of cell debris resulting from the degradation of non-viable cells in the water microcosms. For most of the 4 years of our study, many starved $R$. solanacearum cells retained membrane permeability and proved to be nutrient-responsive, being capable of protein and nucleic acid synthesis as reported for other bacteria (Kogure et al., 1979). Only towards the end of the period, the appearance of starved cells retaining intact membranes (according to Live/Dead staining) but being unable to metabolize the added substrate (according to DVC determination) might indicate that metabolic response is likely to be a more stringent viability criterion than membrane integrity, as suggested by Boulos et al. (1999).

During long starvation, $R$. solanacearum bacilli underwent a progressive transition to coccoid forms as observed in other bacteria (Chaiyanan et al., 2007; Novitsky \& Morita, 1976; Rollins \& Colwell, 1986; Ruiz et al., 2001). Cell volume progressively decreased without significant antigenic change, since cells were readily immunostained, similarly to 2-year-starved Vibrio cholerae (Chaiyanan et al., 2007). A round cell shape and size reduction are assumed to be survival responses as a result of cell divisions, to minimize cell maintenance and better capture scarce nutrients (Chaiyanan et al., 2007; Morita, 1997; Roszak \& Colwell, 1987). In R. solanacearum, size reduction and rise in total and viable cell populations could have been caused by reductive divisions, as commonly reported under long starvation (Byrd, 2000; Morita, 1997; Roszak \& Colwell, 1987). That represents a survival advantage, since a higher number of small and round cells may penetrate narrower and deeper sites looking for food and protecting themselves from predators (Byrd, 2000; Morita, 1997), favouring species perpetuation. The increase in numbers might have been also produced by filamentation and budding phenomena. $R$. solanacearum filamented under starvation conditions, 
as reported for Escherichia coli (Wainwright et al., 1999) and Pseudomonas oleovorans (Ruiz et al., 2001). Some of the $R$. solanacearum filamentous cells were observed to have cell wall evaginations or buds, similarly to starved Campylobacter jejuni (Lázaro et al., 1999; Thomas et al., 1999) and V. cholerae (Chaiyanan et al., 2007); these budded cells are considered as transients in coccoid formation (Thomas et al., 1999). R. solanacearum filamentous cells were visualized by immunostaining as well as bacillar and coccoid cells, as hypothesized by Thomas et al. (1999). This appears to be the first report of filamentation and budding phenomena occurring in a plant-pathogenic bacterium.

Many of the coccoid forms were viable, although non-viable cells were also observed. In our belief and in agreement with Shleeva et al. (2002), in R. solanacearum VBNC populations there could be a co-existence of cells viable enough to be resuscitated and of cells just dying off. Like other bacterial species (Colwell \& Huq, 1994; Chaiyanan et al., 2007; Morita, 1997), $R$. solanacearum coccoid forms showed a tendency to aggregate under starvation, which can be considered a survival mechanism, since cell aggregation enables utilization of the content of lysing cells and protects the cells from environmental hazards such as free radicals, toxins and predators (Blat \& Eisenbach, 1995).

$R$. solanacearum retained virulence during the 4 years of nutrient scarcity in river water microcosms. It had previously been reported to be able to wilt host plants of 132 days of incubation in ultrapure water (van Overbeek et al., 2004). The similar disease incidence on plants steminoculated with $R$. solanacearum either starved (from microcosms) or freshly grown (from controls) during the 4 years demonstrated the great capacity of this pathogen to cause disease. Interestingly, bacterial wilt was also observed in host plants after watering with long-starved $R$. solanacearum, which constitutes a more natural way of transmission of this pathogen. Therefore, a hypothetical water-borne dissemination of disease-causing $R$. solanacearum after extended periods of starvation in environmental waters should not be ruled out, as suggested by field studies (Caruso et al., 2005; Hong et al., 2005).

Oligotrophy is the fundamental factor limiting bacterial survival in open aquatic systems (Morita, 1997), but there are other environmental factors playing a role. The influence of temperature, incident light, presence of sediment, seawater salts and aquatic microbiota on $R$. solanacearum populations has been monitored, also in water microcosms (Álvarez et al., 2007; van Elsas et al., 2001; van Overbeek et al., 2004). Among these factors, only temperature has been assessed in natural water systems, causing a seasonal variation of $R$. solanacearum populations in temperate areas (Caruso et al., 2005; Hong et al., 2005) which did not prevent the survival of the pathogen, even in the presence of aquatic micro-organisms.

Although this work was performed under natural oligotrophic conditions in a confined system, the great ability observed for $R$. solanacearum to persist and cause disease is in agreement with studies in open natural waters, where the bacterium was detected for several consecutive years (Caruso et al., 2005; Hong et al., 2005). Prior to our study, the strategies used by starved $R$. solanacearum ph II bv 2 to survive until contact with the next host were quite unknown. This work revealed a high capacity of this pathogen to adapt itself to prolonged nutrient scarcity in natural water microcosms. It displayed an efficient starvation response, maintaining a nongrowing but culturable population over 4 years, retaining pathogenicity, but also going into a VBNC state. It increased the number of individuals to favour dispersion, reduced its size to reach smaller places, changed from bacilli to cocci to better capture scarce nutrients and aggregated for protection. Overall, this work provides a broader understanding of the long-term survival of $R$. solanacearum under the oligotrophic conditions characteristic of natural waters, which eventually may improve measures to prevent the dissemination of this devastating pathogen in water systems.

\section{ACKNOWLEDGEMENTS}

B. Á. thanks the Instituto Valenciano de Investigaciones Agrarias for a predoctoral grant. The authors wish to thank J. L. Palomo and the Consejería de Agricultura de Castilla-León for collecting the river water samples, J. D. van Elsas for supplying strain IPO-1609, and E. Carbonell, J. Pérez Panadés and J. L. Díez for statistical analysis. This work was funded by projects FAIR 5-CT97-3632 and QLK 3-CT2000-01598 of the European Union, FD 1997-2279 of the Ministerio de Educación y Ciencia of Spain and GV05/214 of the Generalitat Valenciana.

\section{REFERENCES}

Álvarez, B., López, M. M. \& Biosca, E. G. (2007). Influence of native microbiota on survival of Ralstonia solanacearum phylotype II in river water microcosms. Appl Environ Microbiol 73, 7210-7217.

Anonymous (1998). Council Directive 98/57/EC of 20 July 1998 on the control of Ralstonia solanacearum (Smith) Yabuuchi et al. Off $J$ Eur Communities L235, 1-39.

Anonymous (2000). Council Directive 2000/29/EC of 8 May 2000 on protective measures against the introduction into the Community of organisms harmful to plants or plant products and against their spread within the Community. Off J Eur Communities L169, 1112.

Anonymous (2006). Commission Directive 2006/63/EC of 14 July 2006: amending Annexes II to VII to Council Directive 98/57/EC on the control of Ralstonia solanacearum (Smith) Yabuuchi et al. Off $J$ Eur Communities L206, 36-106.

Besnard, V., Federighi, M. \& Cappelier, J. M. (2000). Evidence of viable but non-culturable state in Listeria monocytogenes by direct viable count and CTC-DAPI double staining. Food Microbiol 17, 697704.

Blat, Y. \& Eisenbach, M. (1995). Tar-dependent and -independent pattern formation by Salmonella typhimurium. J Bacteriol 177, 16831691. 
Boulos, L., Prévost, M., Barbeau, B., Coallier, J. \& Desjardins, R. (1999). LIVE/DEAD ${ }^{\circledR}$ BacLight $^{\mathrm{TM}}$ : application of a new rapid staining method for direct enumeration of viable and total bacteria in drinking water. J Microbiol Methods 37, 77-86.

Byrd, J. J. (2000). Morphological changes leading to the nonculturable state. In Nonculturable Microorganisms in the Environment, pp. 7-18. Edited by R. R. Colwell \& D. J. Grimes. Washington DC: American Society for Microbiology.

Caruso, P., Palomo, J. L., Bertolini, E., Álvarez, B., López, M. M. \& Biosca, E. G. (2005). Seasonal variation of Ralstonia solanacearum biovar 2 populations in a Spanish river: recovery of stressed cells at low temperatures. Appl Environ Microbiol 71, 140-148.

Chaiyanan, S., Chaiyanan, S., Grim, C., Maugel, T., Huq, A. \& Colwell, R. R. (2007). Ultrastructure of coccoid viable but non-culturable Vibrio cholerae. Environ Microbiol 9, 393-402.

Colwell, R. R. \& Huq, A. (1994). Vibrios in the environment: viable but nonculturable Vibrio cholerae. In Vibrio Cholerae and Cholera: Molecular to Global Perspectives, pp. 117-133. Edited by I. K. Wachsmuth, P. A. Blake \& Ø. Olsvik. Washington DC: American Society for Microbiology.

Denny, T. P., Brumbley, S. M., Carney, B. F., Clough, S. J. \& Schell, M. A. (1994). Phenotype conversion of Pseudomonas solanacearum: its molecular basis and potential function. In Bacterial Wilt: the Disease and its Causative Agent, Pseudomonas solanacearum, pp. 137-143. Edited by A. C. Hayward \& G. L. Hartman. Wallingford, UK: CAB International.

Elphinstone, J. G. (2005). The current bacterial wilt situation: a global overview. In Bacterial Wilt Disease and the Ralstonia solanacearum Species Complex, pp. 9-28. Edited by C. Allen, P. Prior \& A. C. Hayward. St Paul, MN: APS Press.

Elphinstone, J. G., Hennessy, J., Wilson, J. K. \& Stead, D. E. (1996). Sensitivity of different methods for the detection of Ralstonia solanacearum in potato tuber extracts. EPPO Bull 26, 663-678.

Fegan, M. \& Prior, P. (2005). How complex is the "Ralstonia solanacearum species complex"? In Bacterial Wilt Disease and the Ralstonia solanacearum Species Complex, pp. 449-461. Edited by C. Allen, P. Prior \& A. C. Hayward. St Paul, MN: APS Press.

Grey, B. E. \& Steck, T. R. (2001). The viable but nonculturable state of Ralstonia solanacearum may be involved in long-term survival and plant infection. Appl Environ Microbiol 67, 3866-3872.

Hayward, A. C. (1991). Biology and epidemiology of bacterial wilt caused by Pseudomonas solanacearum. Annu Rev Phytopathol 29, 65-87.

Hayward, A. C. (1994). The hosts of Pseudomonas solanacearum. In Bacterial Wilt: the Disease and its Causative Agent, Pseudomonas solanacearum, pp. 9-24. Edited by A. C. Hayward \& G. L. Hartman. Wallingford: $\mathrm{CAB}$ International.

Heim, S., Lleó, M. D. M., Bonato, B., Guzmán, C. A. \& Canepari, P. (2002). The viable but nonculturable state and starvation are different stress responses of Enterococcus faecalis, as determined by proteome analysis. J Bacteriol 184, 6739-6745.

Hong, J., Ji, P., Momol, M. T., Jones, J. B., Olson, S. M., Pradhanang, P. \& Guven, K. (2005). Ralstonia solanacearum detection in tomato irrigation ponds and weeds. In Proceedings of the First International Symposium on Tomato Diseases, pp. 309-311. Edited by M. T. Momol, P. Ji \& J. B. Jones. Orlando, FL: ISHS.

Kelman, A. (1953). The Bacterial Wilt Caused by Pseudomonas solanacearum. A Literature Review and Bibliography. Raleigh, NC: North Carolina State College.

Kelman, A. (1956). Factors influencing viability and variation in cultures of Pseudomonas solanacearum. Phytopathology 46, 16-17.
Kogure, K., Simidu, U. \& Taga, N. (1979). A tentative direct microscopic method for counting living marine bacteria. Can $J$ Microbiol 25, 415-420.

Lambert, C. D. (2002). Agricultural Bioterrorism Protection Act of 2002: possession, use, and transfer of biological; agents and toxins; interim and final rule (7 CFR Part 331). Fed Regist 67, 76908-76938.

Lázaro, B., Cárcamo, J., Audícana, A., Perales, I. \& FernándezAstorga, A. (1999). Viability and DNA maintenance in nonculturable spiral Campylobacter jejuni cells after long-term exposure to low temperatures. Appl Environ Microbiol 65, 4677-4681.

López, M. M. \& Biosca, E. G. (2005). Potato bacterial wilt management: new prospects for an old problem. In Bacterial Wilt Disease and the Ralstonia solanacearum Species Complex, pp. 205-224. Edited by C. Allen, P. Prior \& A. C. Hayward. St Paul, MN: APS Press.

Morita, R. Y. (1997). In Bacteria in Oligotrophic Environments. StarvationSurvival Lifestyle, pp. 368-385. Edited by C. A. Reddy, A. M. Chakrabarty, A. L. Demain \& J. M. Tiedje. New York: Chapman \& Hall.

Novitsky, J. A. \& Morita, R. Y. (1976). Morphological characterization of small cells resulting from nutrient starvation of a pyschrophilic marine Vibrio. Appl Environ Microbiol 32, 617-622.

Oliver, J. D. (1987). Heterotrophic bacterial populations of the Black Sea. Biol Oceanogr 4, 83-97.

Oliver, J. D. (2005). The viable but nonculturable state in bacteria. $J$ Microbiol 43, 93-100.

Ridé, M. (1969). Bactéries phytopathogènes et maladies bactériennes des végétaux. In Les Bactérioses et les Viroses des Arbres Fruitiers, pp. 4-59. Edited by M. Ponsot. Paris: Viennot-Bourgin.

Rollins, D. M. \& Colwell, R. R. (1986). Viable but nonculturable stage of Campylobacter jejuni and its role in survival in the natural aquatic environment. Appl Environ Microbiol 52, 531-538.

Roszak, D. B. \& Colwell, R. R. (1987). Survival strategies of bacteria in the natural environment. Microbiol Rev 51, 365-379.

Ruiz, J. A., López, N. I., Fernández, R. O. \& Méndez, B. S. (2001). Polyhydroxyalkanoate degradation is associated with nucleotide accumulation and enhances stress resistance and survival of Pseudomonas oleovorans in natural water microcosms. Appl Environ Microbiol 67, 225-230.

Shleeva, M. O., Bagramyan, K., Telkov, M. V., Mukamolova, G. V., Young, M., Kell, D. B. \& Kaprelyants, A. S. (2002). Formation and resuscitation of "non-culturable" cells of Rhodococcus rhodochrous and Mycobacterium tuberculosis in prolonged stationary phase. Microbiology 148, 1581-1591.

Tanaka, Y. \& Noda, N. (1973). Studies on the factors affecting survival of Pseudomonas solanacearum E.F. Smith, the causal agent of tobacco wilt disease. Bull Okayama Tobacco Exp Stn 32, 81-94.

Thomas, C., Hill, D. J. \& Mabey, M. (1999). Morphological changes of synchronized Campylobacter jejuni populations during growth in single phase liquid culture. Lett Appl Microbiol 28, 194-198.

van Elsas, J. D., Kastelein, P., van Bekkum, P., van der Wolf, J. M., de Vries, P. M. \& van Overbeek, L. S. (2000). Survival of Ralstonia solanacearum biovar 2, the causative agent of potato brown rot, in field and microcosm soils in temperate climates. Phytopathology $\mathbf{9 0}$, 1358-1366.

van Elsas, J. D., Kastelein, P., de Vries, P. M. \& van Overbeek, L. S. (2001). Effects of ecological factors on the survival and physiology of Ralstonia solanacearum bv. 2 in irrigation water. Can J Microbiol 47, 842-854.

van Elsas, J. D., van Overbeek, L. S. \& Trigalet, A. (2005). The viable but non-culturable state in Ralstonia solanacearum: is there a realistic threat to our strategic concepts? In Bacterial Wilt Disease and the Ralstonia solanacearum Species Complex, pp. 103-119. Edited by C. Allen, P. Prior \& A. C. Hayward. St Paul, MN: APS Press. 
van Overbeek, L. S., Bergervoet, J. H. W., Jacobs, F. H. H. \& van Elsas, J. D. (2004). The low-temperature-induced viable-butnonculturable state affects the virulence of Ralstonia solanacearum biovar 2. Phytopathology 94, 463-469.

Wainwright, M., Canham, L. T., al-Wajeeh, K. \& Reeves, C. L. (1999). Morphological changes (including filamentation) in Escherichia coli grown under starvation conditions on silicon wafers and other surfaces. Lett Appl Microbiol 29, 224-227.

Wakimoto, S., Utatsu, I., Matsuo, N. \& Hayashi, N. (1982). Multiplication of Pseudomonas solanacearum in pure water. Nippon Shokubutsu Byori Gakkaiho 48, 620-627.

Edited by: D. M. Gordon 